\title{
SISTEM DEIKSIS PERSONA DALAM TINDAK KOMUNIKASI
}

\author{
Oleh: Teguh Setiawan
}

\begin{abstract}
Abstrak
Sistem deiksis persona sebagai salah satu aspek bahasa merupakan pendukung tercapainya tujuan tindak komunikasi. Hal ini mengingat dalam tindak komunikasi penutur tidak akan selamanya menggunakan nama dirinya dan nama lawan tuturnya, akan tetapi akan bervariasi dengan mengunakan kata ganti persona baik untuk merujuk dirinya maupun untuk merujuk lawan tuturnya

Dalam bahasa Indonesia penggunaan sistem deiksis persona merujuk pada penggunaan sistem bentuk kata ganti persona (pronomina persona) yang memiliki bentuk dan fungsi yang berbeda-beda. Bentuk pronomina persona pertama pada umumnya merujuk pada pembicara akan tetapi tindak menutup kemungkinan merujuk pada lawan bicara. Bentuk pronomina persona kedua merujuk pada lawan bicara dan dapat pula merujuk pada pembicara dan pihak ketiga diluar pembicara dan lawan bicara, sedangkan bentuk pronomina persona ketiga pada umumnya merujuk pada orang ketiga tetapi tidak menutup kemungkinan merujuk pada pembicara. Dalam pemakainnya bentuk-bentuk deiksis tersebut tidak dapat digunakan secara acak. Hal ini disebabkan deiksis persona merupakan sistem yang sangat terikat oleh kaidah dan latar belakang budaya bahasa yang bersangkutan. Oleh karena itu perlu adanya deskripsi yang jelas tentang kaidah yang berlaku pada sistem deiksis ahasa Indonesia guna mendukung tercapianya tujuan komunikasi.
\end{abstract}

\section{A. Pendahuluan}

Bahasa merupakan salah satu hasil budaya manusia yang sangat tinggi nilainya karena dengan bahasa manusia dapat berkomunikasi dan berinteraksi dengan masyarakat di sekitarnya. Dengan bahasa pula, manusia dimungkinkan dapat berkembang dan mengabstraksikan berbagai gejala yang muncul di lingkungannya. Jelaslah bahwa bahasa sangat penting peranannya dalam kehidupan sosial.

Komunikasi akan berjalan dengan lancar apabila sasaran bahasa yang digunakan tepat. Artinya bahasa itu dipergunakan sesuai dengan situasi dan kondisi penutur dan sifat penuturan itu dilaksanakan. Hal ini sangat bergantung pada faktor-faktor penentu dalam tindak bahasa atau tindak komunikasi, yaitu lawan bicara, tujuan pembicara, masalah yang dibicarakan, situasi. Penggunaan bahasa seperti inilah yang disebut pragmatik.

Pragmatik mangkaji empat hal, yaitu deiksis, praanggapan, tindak 
ujaran, dan implikatur percakapan (Purwo, 1990:17). Deiksis sebagai salah satu kajian pragmatik merupakan gejala semantis yang terdapat pada kata atau konstruksi yang hanya dapat ditafsirkan acuannya dengan memperhitungkan situasi pembicaraan. Sebuah kata dikatakan bersifat deiksis apabila rujuakkan kata-kata itu berpindah-pindah atau berganti-ganti, tergantung pada saat dan tempat dituturkannya kata itu (Purwo, 1984:1). Kata-kata seperti saya, dia, kamu, merupakan kata-kata yang bersifat deiksis. Rujukan kata-kata tersebut barulah dapat diketahui jika diketahui pula siapa, di aman, dan pada waktu kapan kata-kata itu diucapkan. Peristiwa deiksis dapat terjadi pada bahasa lisan maupun tulisan dan dapat pula berupa deiksis persona, deiksis tempat, deiskis waktu, deiksis sosial, dan deiksis wacana.

Kata-kata deiksis pada setiap bahasa jumlahnya terbatas. Walau demikian, sistem deiksis justru termasuk yang sangat sulit dipelajari orang yang bukan penutur asli bahasa yang bersangkutan (Purwo, 1980:18). Hal ini berarti kajian deiksis bahasa Indonesia akan lebih mendalam apabila orang yang mengakaji adalah penutur asli bahasa Indonesia.

Sistem deiksis bahasa yang satu dengan bahasa yang lain adalah berbeda. Hal ini dimungkinkan karena tiap-tiap bahasa memiliki kaidah bahasa dan latar belakang budaya tersendiri yang berbeda dengan kaidah latar belakang budaya bahas yang lain. Perbedaan ini membawa konsekuensi tersendiri bagi orang yang akan mempelajari atau mendalami dan menggunakannya dalam tindak komunikasi. Dalam bahasa Inggris untuk menunjuk orang kedua tunggal cukup dengan menggunakan kata you tanpa memandang siapa yang diajak bicara. Apakah yang diajak bicara itu seorang anak, pemuda, orang tua, tidaklah menjadi persoalan. Dalam bahasa Indonesia tidaklah demikian, untuk menunjuk orang kedua tunggal, seseorang harus tahu terlebih dahulu siapa yang diajak berbicara dan bagaimana situasi pembicaraan tersebut. Semua ni harus diperhitungkan oleh penutur bahasa Indonesia sebab hal ini akan menentukan bentuk persona yang akan dipilih. Apakah akan memilih bentuk kamu, anda, ataukah saudara yang kesemua bentuk persona tersebut memiliki beban semantik dan karakteristik yang berbeda-beda. Dengan demikian persolannya adalah beban semantik dan karakteristik apa saja yang dimiliki oleh masing-masing bentuk deiksis yang ada di dalam bahasa Indonesia yang selanjutnyan menjadi sistem deiksis persona dalam bahasa tersebut ? Pengetahuan tentang itu akan sangat penting guna membantu dan mendukung terncapainya tujuan komunikasi. 


\section{B. Pengertian Pragmatik}

Pragmatik sebagaimana yang telah diperbincangkan di Indonesia dewasa ini, paling tidak dapat dibedakan atas dua hal, yaitu (1) pragmatik sebagai sesuatu yang diajarkan (2) pragmatik sebagai suatu yang mewarnai tindakan mengajar.Bagian pertama sebagai bidang kajian linguistik dan kedua pragmatik sebagai salah satu segi di dalam bahasa atau disebut fungsi komunikatif (Purwo, 1990:2).

Istilah pragmatik itu sendiri dapat ditelusuri kehadiranya dengan menyangkutpautkan filosof yang bernama Charles Morries (1978). Ia sebenarnya mengambil pemikiran para filosof pendahulunya (Locke dan Pierce) mengenai semiotik, oleh Moris dipilah menjadi tiga cabang yaitu sintaksis, semantik dan pragmatik (Moris, 1946: 217 dalam lyons, 1978:115).

Pragmatik dan semantik sama-sama mengkaji tentang makna. Salah satu upaya untuk memberi batas antara semantik dan pragmatik terlihat pada definisi berikut. Pragmatik adalah telah mengenai segala aspek mana yang tercakup di dalam teori semantik. Sedangkan semantik adalah makna kalimat. Pragmatik menekankan pada tuturan (Purwo, 1990 : 16). Dengan demikian semantik menggeluti makna kata atau klausa, tetapi makna pragmatik memberikan makna yang terikat konteks (context dependent). Hal ini sejalan dengan pengertian pragmatik yang dikemukakan ooleh Victoria dan Robert (1978 : 189), yaitu pramatics is the general study of how context influence the way we interpret sintences atau pragmatik merupakan studi umum tentang agaimana pengaruh kontek terhadap cara kita menafsirkan kalimat

Ruang lingkup pragmatik itu mencakup beberapa kajian. Levinson (1983 : 37) mengatakan pragmatics is the study of deixis (at least in past) implicatur, presupposition, speech acts, and aspect of discourse structure. Dengan kata lain pragmatik adalah kajian mengenai deiksis, implikatur, pranggapan tindak tutur dan aspek struktur wacana. Menurut Nababan (1987:18) kajian pragmatik mencakup variasi bahasa, tindak bahasa, implikatur percakapan, teori deiksis. praanggapan dan analisis wacana. sementara itu Purwo (1984:10) mengatakan ada empat yang disepakati dalam kajian pragmatik yaitu (1) deiksis, (2) pranggapan. (3) tindak ujar, dan (4) implikatur percakapan.

\section{Pengertian Deiksis}

Dalam kegiatan berbahasa, sering digunakan kata-kata atau frase-frase 
yang maknanya menunjukan pada bentuk yang lain. Menurut Bambang Kaswanti Purwo (1984:1) sebuah kata dikatakan bersifat deiksis apabila rujukannya berpindah-pindah atau berganti-ganti, tergantung pada siapa yang menjadi pembicara, saat dan tempat dituturkannya kata-kata itu. Oleh karena itu, deiksis dapat dikatakan sebagai "an expresion thar. has one meaning but refers to different entities as the extralinguistics context change" (Nirmala, 1988:51). Dalam bidang linguistik terdapat pula istilah rujukan atau sering disebut referensi, yaitu kata atau frase yang menunjuk kepada kata, frase atau ungkapan yang akan diberikan. Rujukan semacam itu oleh Nababan (1987:40) disebut deiksis.

Pengertian deiksis menurut pandangan tradisional dibedakan dengan pengertian anafora. Deiksis diartikan sebagai luar tuturan. Menutur pandangan yang menjadi pusat orientasi deiksis senantiasa si pembicara, yang tidak merupakan unsur di dalam bahasa itu sendiri, sedangkan anafora merujuk dalam tuturan baik yang mengacu pada kata yang berada dibelakang maupun yang merujuk pada kata yang beradaa di depan (Lyons, 1977:638). Semantara Nansi J. (1983:181) memberikan definisi deiksis sebagai rujukan suatu kata yang berpindah dan bergantung pada siapa yang berbicara, di mana pembicara atau pendengar dan waktu dituturkannya kata-kata tersebut.

Kata deiksis berasal dari kata Yunani deiktikos yang berarti 'hal menunjuk secara langsung'. Sedangkan istilah deiktikos yang dipergunakan oleh tata bahasawan Yunani dalam pengertian sekarang kita sebut kata ganti demonstratif. Tata bahasawan Roman (Stoics, Dionysius Trax, dan Apollonius Dyscolus yang melekatkan dasr bagi timbulnya tata bahasa tradisional di dunia barat) memakai kata demonstrativus untuk menerjemahkan kata deiktikos (Lyons, 1977:639). Dalam lingustik sekarang kata itu dipakai untuk menggambarkan fungsi kata ganti persona, kata ganti demonstratif, fungsi waktu dan macam-macam ciri gramatikal dan leksikal lainnya yang mengabungkan ujaran dengan jalinan ruang dan waktu dalam tindak ujaran.

\section{Macam Deiksis.}

Dalam kajian pragmatik ada beberapa kreterian pembagian deiksis, Nansi J. (1983:18) membagi deiksis atas tiga macam, yaitu deiksis persona, deiksis tempat dan deiksis waktu. Pembagian ini sejalam dengan apa yang dilakukan oleh Bambang Kawwanti Purwo (1994:19) dan Victoria dan Robert (1987:91). Sedangkan Nababan (1987:41) membagi deiksis 
menjadi lima macam, yaitu deiksis persona, deiskis tempat, deiksis waktu, deiksis wacana, dan deiksis sosial.

\section{E. Pengertian Deiksis Persona}

Deiksis persona adalah pemberian bentuk kepada peran peserta dalam kegiatan berbahasa. Dalam kategori deiksis persona yang menjadi kreteria adalah peran/peserta dalam peristiwa berbahasa itu. Peran dalam kegiatan berbahasa itu dibedakan menjadi tiga macam, yaitu persona pertama, persona kedua, dan persona ketiga (Haliday dan Hasan, 1984:44). Dalam sistem ini, persona pertama kategorisasi rujukan pembicara kepada dirinya sendiri, persona kedua ialah kategorisasi rujukan pembicara kepada pendengar atau si alamat, dan persona ketiga adalah kategorisasi rujukan kepada orang atau benda yang bukan pembicara dan lawan bicara.

Deiksis persona merupakan deiksis asli, sedangkan deiksi waktu dan deiksis tempat adalah deiksis jabaran. Hal ini didasarkan atas pendapat Becker dan Oka dalam Purwo (1984:21) bahwa deiksis persona merupakan dasar orientasi bagi deiksis ruang dan tempat serta waktu.

\section{F. Sistem Deiksis Persona dalam Komunikasi}

Sistem persona merupakan sistem yang pertama kali di-gunakan oleh anak-anak yang berumur dua tahun (Bloom, Lightbown, Hood (1975) dan Nansi J. (1983:181). hal ini sejalan dengan hasil penelitian Tanz (1980) dalam Nansi J. (1983:182) terhadap tingkat-tingkat perkembangan penggunaan bahasa pada anak-anak yang berkesimpulan bahwa ada banyak anak yang sudah menguasai sistem deiksis persona pada umur dua tahun, terutama bentuk saya, kamu, dia, sedangkan bentuk-bentuk lainnya belum dikuasi dan diketahui banyak oleh mereka. Oleh karena itu, dapat dikatakan bahwa deiksis persona merupakan deiksis asli, sedangkan deiksis waktu dan deiksis tempat merupakan deiksis jabaran.

Penggunaan sistem deiskis persona dalam tindak komunikasi tidak hanya harus menguasai kaidah bahasanya tetapi juga harus memperhatikan latar belakang budaya bahasa tersebut. Tanpa memperhatikan dua hal ini dapat dimungkinkan tindak komunikasi tidak akan berhasil. Sebagai contoh seorang mahasiswa Australia menggunakan bentuk kamu untuk memanggil seorang dosen di Indonesia. Bentuk tersebut dirasa kurang tepat karena bentuk kata ganti persona tersebut umumnya digunakan oleh seorang pembicara yang mempunyai hubungan akrab dengan lawan bicara 
atau dari orang yang lebih tua ke yang muda. Sementara itu ada bentuk lain yang sama-sama untuk merujuk pada orang kedua tetapi khusus untuk memanggil seorang dosen yaitu bapak atau ibu sehingga apabila bentuk kamu yang dipilih komunikasi akan terganggu bahkan mungkin akan terputus.

Sehubungan dengan ketepatan pemilihan bentuk deiksis persona ,maka harus diperhatikan fungsi bentuk-bentuk kata ganti persona dalam bahasa Indonesia. Ada tiga bentuk kata ganti persona, yaitu (1) kata ganti persona pertama, (2) kata ganti persona kedua, dan (3) Kata ganti persona ketiga.

\section{Kata Ganti Persona Pertama}

Kata ganti persona pertama adalah kategorisasi rujukanpembicara kepada dirinya sendiri. Dengan kata lain kata ganti persona pertama merujuk pada orang yang sedang berbicara. Kata ganti persona pertama dibagi menjadi dua, yaitu kata ganti persona pertama tunggal dan kata ganti persona pertama jamak.

Kata ganti persona pertama tunggal mempunyai tiga bentuk, yaitu aku, saya, daku (P\&K, 1988:17). Kata ganti persona pertama aku merupakan kata ganti yang sebenarnya (asli), sedangkan bentuk saya merupakan kata ganti persona pinjaman dari bentuk sahaya (Slametmuljono, 1957:54). Bentuk aku mempunyai dua variasi bentuk, yaitu -ku dan ku-, sedangkan bentuk saya tidak mempunyai variasi bentuk. Berdasarkan distribusi sintaksisnya bentuk -ku merupakan bentuk lekat kanan, sedangkan bentuk ku-merupakan bentuk lekat kiri. Betuk lekat kanan seperti itu dalam bahasa Indonesia dapat dijumpai dalam konstruksi posesif dan dalam konstruksi posesif bentuk persona senantiasa lekat kanan (Sudaryanto, 1979).

Contoh :

(1) "Tidak ! Bongkrekku tidak mungkin beracun ..." (Ronggeng Dukuh Paruk, hlm:34)

Di samping digunakan dalam konstruksi posesif bentuk -ku dapat pula menduduki fungsi objek dan berperan objektif (Purwo, 1984:27).

Contoh :

(2) "Dia masih menatapku dengan cara seorang yang bodoh." (Ronggeng Dukuh Paruk, hlm:84) 
Bentuk ku- sebagai bentuk lekat kiri dalam hal pemakaiannya sama sekali berbeda dengan bentuk -ku. Bentuk ku- umumnya diletakan pada kata yang terletak disebelah kirinya, dalam rangkaian verba dan mengisi gatra konstituen pelaku.

Contoh :

(3) "Lebih baik sekarang ku hadapi hal yang lebih nyata." (Ronggeng Dukuh Paruk, hlm:51)

Selain bentuk kata ganti persona, digunakan pula nama-nama orang untuk menunjuk persona pertama tunggal (Samsuri, 1987:238). Anak-anak biasa memakai nama diri untuk merujuk, pada dirinya misalnya seorang anak bernama agus suatu ketika dia ingin makan dan dia mengucapkan "Agus mau makan" yang berarti 'Aku mau makan' (bagi diri Agus). Akan tetapi apabila kalimat itu diucapkan oleh seorang ayah atau seorang ibu dengan nada bertanya seperti "Agus mau makan?" maka nama Agus tidak lagi merujuk pada pembicara tetapi merujuk pada persona kedua tunggal (mitra tutur).

Dalam hal pemakainnya, bentuk persona pertama aku dan saya ada perbedaan. Bentuk saya adalah bentuk yang formal dan umumnya dipakai dalam tulisan atau ujaran yang resmi. Untuk tulisan formal pada buku nonfiksi, pidato, sambutan bentuk saya banyak digunakan bahkan pemakian bentuk saya sudah menunjukan rasa hormat dan sopan. Namun demikian tidak menutup kemungkinan bentuk saya dipakai dalam situasi nonformal. Sebaliknya dengan bentuk aku lebih banyak dipakai dalam situasi yang tidak formal serta lebih menunjuk keakraban antara pembicara dan lawan bicara. Dengan kata lain bentuk saya tak bermarkah, sedangkan bentuk aku bermarkah keintiman (marked for intimacy) (Purwo, 1983:23).

Contoh:

(4) "Aku tidak pasti lagi, Mas Sun. Mungkin sekali yang mendorongku adalah Hasan suamiku" (Bawuk, hlm:141)

(5) "Aku harap aku betul, sungguh darling, aku serius. aku harap itu betul" (Seribu Kunang-Kunang di Manhattan, hlm:158)

(6) "Ah bukan saya tapi sama Kanjeng. Masa ondernya dulu." (Bawuk, hlm:112)

(7) "Setujukah Tuan dengan pendapat saya bahwa di Amerika tidak ada jam baik seperti di Swiss ?" (There Goes Tatun, hlm:237) 
Bentuk kata ganti persona pertama aku pada kalimat (3) dan (4) bernada akrab dan digunakan dalam situasi yang tidak formal, sedangkan bentuk saya pada kalimat (5) dan (6) digunakan dalam tuturan yang bernada formal.

Bentuk dan fungsi persona pertama tunggal berbeda dengan bentuk dan fungsi kata ganti persona pertama jamak. Bentuk kata ganti persona jamak meliputi kami dan kita. Dalam bahasa Inggris, baik untuk merujuk bentuk kami maupun kita hanya menggunakan satu bentuk, yaitu we. Bentuk we yang berarti kami akan meliputi ( $I$, she, he, dan they) tanpa you sebagai lawan bicara, sedangkan bentuk we yang berarti kita akan meliputi (I, she, he, they, dan you) (Halliday dan Hasan, 1984:50).

Bentuk persona pertama jamak kami merupakan bentuk yang bersifat ekslusif artinya bentuk persona tersebut merujuk pada pembicara atau penulis dan orang lain dipihaknya, akan tetapi tidak mencakup orang lain dipihak lawan bicara. Selain itu, bentuk kami juga sering digunakan dalam pengertian tunggal untuk mengacu kepada pembicara dalam situasi yang formal. Dengan demikian, kedudukan kami dalam hal ini mengggantikan persona pertama tunggal, yaitu saya (P\&K, 1988:174). Hal ini berhubungan dengan sikap pemakai bahasa yang sopan mengemukakan dirinya dan karenanya menghindari bentuk saya. Sebaliknya dengan bentuk kita, bentuk ini bersifat inklusif artinya bentuk pronomina tersebut merujuk pada pembicara/penulis, pendengar/pembaca dan mungkin pihak lain (Leech, 1979:84). Oleh karena itu, bentuk kita biasanya digunakan oleh pembicara sebagai usaha untuk mengakrabkan atau mengeratkan hubungan dengan lawan bicara.

Contoh :

(8) "Alangkah cerdas mereka. Tentu saja kita adalah pemain kabuki." (Kimono Biru Buat Istri, hlm:315)

(9) "Kalau ibu tahu di mana mereka, lapor kami ya Bu." (Sri Sumarah, hlm:56)

Dalam situasi yang berbeda bentuk kami memiliki rujukan dan makna yang berbeda. Sebagai contoh bentuk kami yang digunakan oleh seorang presiden atau seorang raja saat berbicara dengan rakyatnya, bukanlah untuk merujuk pembicara tunggal guna mencapai kadar kesopanan tetapi bentuk kami tersebut mewakili dirinya (raja atau presiden) dengan 
segenap pembantunya dan kekuasaanya. Bentuk persona pertama selain merujuk pada pembicara kemungkinannya juga merujuk pada lawan bicara (persona kedua). Hal ini disebabkan oleh adanya perbedaan konteks penuturan.

Contoh :

(10) Wah bajuku baru! Pantas gayanya lain.

Bentuk kata ganti persona pertama -ku pada kalimat (10) merujuk pada lawan bicara bukan untuk merujuk pembicara. Penggunaan bentuk deiskis semacam itu biasanya digunakan oleh seorang pembicara yang sudah dewasa kepada anak kecil tau untuk menyinggung lawan bicara karena lawan bicaranya memakai baju baru.

\section{Kata Ganti Persona Kedua}

Kata ganti persona kedua adalah kategorisasi rujukan pembicara kepada lawan bicara . Dengan kata lain bentuk kata ganti persona kedua baik tunggal maupun jamak merujuk pada lawan bicara.

Bentuk pronomina persona kedua tunggal adalah kamu dan engkau. Kedua bentuk kata ganti persona kedua tunggal tersebut masing-masing mempunyai bentuk variasi -mu dan kau-. Bentuk persona ini biasanya dipergunakan oleh:

a) Orang tua terhadap orang muda yang telah dikenal dengan baik dan lama

b) Orang yang mempunyai status sosial lebih tinggi untuk menyapa lawan bicara yang statusnya lebih rendah.

c) Orang yang mempunyai hubungan akrab, tanpa memandang umur atau status sosial (Purwo, 1984:23).

Contoh :

(11) "Kau tak usah ragu tentang hal itu. Baiklah aku akan mengganti pertanyaan itu kalau kau mau " (Bawuk, hlm:143)

(12) "...Maukah kau membikin aku segelas" (Seribu Kunangkunang di Manhattan, hlm:156)

(14) "Kalau begitu, kenapa tidak di sini saja menuggu suamimu itu" (Bawuk, hlm:141)

Sebutan ketaklaziman untuk pronomina persona kedua dalam bahasa Indonesia banyak ragamnya, seperti anda, saudara, leksim kekerabatan seperti bapak, ibu, kakak dan leksem jabatan seperti guru, dokter. Pemilihan bentuk mana yang harus dipilih ditentukan oleh aspek 
sosiolinguistik. Bentuk bapak/pak, ibu/bu yang merupakan bentuk sapaan kekeluargaan menandakan dua pengertian. Pertama, orang yang mamakai bentuk-bentuk tersebut memiliki hubungan akrab dengan lawan bicaranya. Kedua, dipergunakan untuk memanggil orang yang lebih tua atau orang yang belum dikenal. Dengan kata lain pengertian kedua menandakan hubungan antara pembicara dengan lawan bicara kurang akrab, sedangkan bentuk saudara, anda biasanya digunakan untuk menghormat dan ada jarak yang nyata antara pembiacar dan lawam bicara. Khusus untuk bentuk ketakziman anda biasanya dimaksudkan untuk menetralkan hubungan. Meskipun kata itu telah lama dipakai tetapi struktur nilai sosial budaya kita masih membatasi pemakaian kata ganti tersebut. Pada saat ini kata ganti tersebut dipakai :

1. Dalam hubungan yang tak pribadi sehingga bentuk anda tidak diarahkan pada satu orang khusus;

2. Dalam hubungan bersemuka tetapi pembicara tidak ingin terlalu formal ataupun terlalu akrab.

Contoh :

(15) "Ibu mau ke mana ?" (Bawuk, hlm:139)

(16) "Bu, Yos dan Tun ke mana, Bu ?" (Sri Sumarah, hlm:55)

(17) "Saudara harus ikut ka,i sekarang ..." (MGKC, hlm:270)

(18) "Saudara. Saudara, Bung Tono, bukan ?" (MGKC, hlm:270)

Khusus untuk leksim kekerabatan seperti ibu, bapak, dan kakak disamping merujuk pada lawan bicara (persona kedua) dapat juga merujuk pada pembicara (persona pertama) dan orang yang tidak telibat secara langsung dalam tindak komunikasi (persona ketiga).

Contoh :

(19) "Ibu masih kangen. engkau anak nakal tak bisa dikangeni." (Tiga Kota, hlm:50)

(20) "Memang mungkin ibu akan sulit mendapatkan sawah ibu kembali." (Sri Sumarah, hlm:43)

(21) "Bapak tidak akan pulang dari sorga. Mari kita pulang manis, mari kita pulang." (Tiga Kota, hlm16)

(22) "Nanti kalau ibu sudah ketemu bapak akan datang menjemput Wowok dan Ninuk ?" (Bawuk, hlm:140)

Pada konteks kalimat (19) dan (20), bentuk ibu tidak lagi digunakan untuk merujuk pada lawan bicara seperti biasanya orang menggunakan 
tetapi digunakan untuk merujuk pembicara. Demikian juga pada kalimat (21) dan (22), bentuk bapak pada kedua kalimat tersebut bukan untuk merujuk pada lawan bicara tetapi untuk merujuk orang ketiga yang tidak hadir pada saat tuturan tersebut diucapkan.

Leksim kekerabatan yang merujuk pada pembicara dan orang ketiga biasanya digunakan apabila antara pembicara dan lawan bicara memiliki hubungan kekeluargaan atau hubungan kerabat yang akrab. Misalnya, orang tua biasanya akan menggunakan bentuk yang disesuaikan dengan kedudukannya dalam keluarga (bapak atau ibu) apabila sedang berbicara dengan anaknya atau dengan orang lain yang masih memiliki hubungan keluarga.

Bentuk persona kedua di samping mempunyai bentuk tunggal seperti tersebut di atas juga mempunyai bentuk jamaknya, yaitu kalian dan bentuk persona kedua tunggal yang ditambah dengan kata sekalian, seperti anda sekalian, kamu sekalian. meskipun bentuk kalian tidak terikat pada tata krama sosial, yang status sosialnya lebih rendah umumnya tidak memakai bentuk itu terhadap orang yang lebih tua atau orang yang bersatus sosial lebih tinggi.

Contoh :

(23) "Ya. Kalian harus tinggal sana Eyang. Kalian mesti lah lagi" (Bawuk, hlm:139)

(24) "Wok, Nuk, besok kalian ibu antar ke rumah Eyang" (Bawuk, hlm:139)

\section{Kata Ganti Persona Ketiga}

Bentuk kata ganti persona ketiga merupakan kategori-sasi rujukan pembicara kepada orang yang berada di luar tindak komunikasi. Dengan kata lain bentuk kata ganti persona ketiga merujuk orang yang tidak berada baik pada pihak pembicara maupun lawan bicara.

Bentuk kata ganti persona ketiga dalam bahasa Indonesia ada dua, yaitu bentuk tunggal dan bentuk jamak. Bentuk tunggal pronomina persona ketiga mempunyai dua bentuk, yaitu ia dan dia yang mempunyai variasi -nya. Meskipun bentuk ia dan dia dalam banyak hal berfungsi sama, namun ada perbedaan tertentu yang dimiliki oleh kedua jenis kata ganti persona tersebut. Perbedaan tersebut adalah karena membawa ciri penegas atau penekanan. Dalam teks bahasa Melayu dapat ditemukan bentuk ia (lah) yang membawa ciri penegas. Dimungkinkannya bentuk ia membawa ciri penegas karena dalam bahasa Melayu tidak ada bentuk ialah yang mirip dengan kata adalah dalam 
bahasa Indonesia. Persamaanya adalah dapat berposisi sebagai subjek. Selain kedua bentuk tersebut, dikenal juga bentuk ketakziman seperti bentuk beliau.

Dalam hal pemakaiannya, bentuk dia dan ia berbeda dengan bentuk beliau. Bentuk dia dan ia umumya digunakan oleh pembicara tanpa ada maksud untuk menghormati orang yang dirujuk, sedangkan bentuk beliau digunakan oleh pembicara untuk merujuk kepada orang lain yang patut untuk dihormati walaupun lebih muda dari pembicara.

Contoh :

(25) "Dia, kan yang memegang sawah ibu ?" (Sri Sumarah, hlm:43)

(26) "lho, apa dia belum tahu dia itu anak siapa ?" (Sri Sumarah, hlm:68)

(27) "Ia bersembunyi di gang pintu keluar kereta." (Stasiun, hlm:38)

(28) „Ibu yang menggadaikan sawah itu kepadanya” (Sri Sumarah, hlm:43)

Bentuk pronomina persona ketiga jamak adalah mereka Di samping arti jamaknya, bentuk mereka berbeda dengan kata ganti persona ketiga tunggal dalam acuannya. Pada umumnya bentuk pronomina persona ketiga hanya untuk merujuk insani. Akan tetapi pada karya sastra, bentuk mereka kadang-kadang dipakai untuk merujuk binatang atau benda yang dianggap bernyawa. Bentuk pronomina persona ketiga jamak ini tidak mempunyai variasi bentuk, sehingga dalam posisi manapun hanya bentuk itu yang dipergunakan. Penggunaan bentuk persona ini digunakan untuk hubungan yang netral, artinya tidak digunakan untuk lebih menghormati atau pun sebaliknya.

Contoh:

(29) "Mau mereka ? Bisa tidur lho" (Kimono Biru Buat Istri, hlm:306)

(30) "Sejak dua hari terakhir itu mereka berdatangan." (Bawuk, hlm:119)

Kata ganti persona ketiga selain merujuk pada orang ketiga juga kemungkinannya merujuk pada persona pertama dan persona kedua. Adanya Kemungkinan rujukan lain merupakan akibat adanya perbedaan konteks penuturan. 
Contoh:

(31) Seperti penulis sebutkan di atas ...

(32) Namanya siapa ? Tinggalnya di mana ?

Pada kalimat (31) bentuk penulis tidak merujuk pad persona ketiga, tetapi merujuk pada si pembicara, sedangkan pada kalimat (32) bentuk -nya merujuk pada lawan bicara (persona kedua) bukan pada persona ketiga.

\section{G. Kesimpulan}

Penggunaan sistem deiksis persona dalam tindak komuni-kasi yang merujuk pada penggunaan bentuk dan fungsi kata ganti persona (pronomina persona) mempunyai beberapa ketentuan.

1. Bentuk pronomina persona pertama terdiri atas bentuk tunggal (saya, aku, nama diri) dan jamak (kami, kita). Bentuk persona pertama tunggal merujuk pada diri penutur. Bentuk aku cenderung digunakan dalam situasi informal dan bermarkah keintiman. Selain itu bentuk ini lebih menonjolkan sifat individu bila dibandingkan dengan bentuk saya. Bentuk saya digunakan dalam situasi formal dan sekaligus untuk menandakan rasa hormat dan sopan. Sementara itu bentuk kami umumnya merujuk pada diri penutur dan orang yang berada di pihak penutur, akan tetapi untuk mencapai kadar kesopanan bentuk ini juga sering digunakan oleh penutur untuk merujuk dirinya. Sedangkan bentuk kita digunakan untuk merujuk penutur dan lawan tutur dengan tujuan untuk mengakrabkan. .

2. Bentuk pronomina kedua terdiri atas bentuk tunggal (kamu, engkau) dan bentuk jamak (dengan menambah kata sekalian pada bentuk tunggal) serta bentuk-bentuk ketakziman anda, saudara,) termasuk leksim kekerabatan seperti ibu, bapak, dan kakak. Bentuk kamu dan engkau digunakan oleh orang tua kepada yang lebih muda atau mereka yang memiliki hubungan akrab. Oleh karena itu dalam bahasa Indonesia tidak akan mungkin diterima bentuk tersebut digunakan untuk merujuk ayah atau ibu. Sebagai gantinya biasnya digunakan leksim. kekerabatan seperti ayah dan ibu. Sedangkan bentuk anda dan saudara digunakan untuk menandai hubungan yang kurang akrab dan ada jarak antara penutur dan lawan tutur. Bentuk ini sekaligus untuk menghormat lawan tuturnya. Sementara bentuk jamak untuk merujuk lawan tutur yang lebih dari satu dan dalam hal ini penutur lebih tua dari lawan tutur. 
3. Bentuk pronomina ketiga memiliki bentuk tunggal (dia dan ia) dan jamak (mereka), serta bentuk ketakziman (beliau). Bentuk dia dan ia merujuk pada orang ketiga tunggal dan digunakan dalam hubungan netral bukan untuk menghormat. Apabila penutur akan menghormati pada orang ketiga maka akan digunakan bentuk beliau. Sedangkan . bentuk mereka sebagai bentuk jamak persona ketiga digunakan untuk hubungan yang netral artinya tidak digunakan untuk lebih menghormati atau sebaliknya.

\section{DAFTAR PUSTAKA}

Depdikbud. 1988. Tata Bahasa Baku Bahasa Indonesia. Jakarta: PN Balai Pustaka

Frankrin, Victoria dan Robert Kodman. 1984. An Introduction to Language. New Jersy :Rinehart and Winston Inc

Halliday, M.A.K. dan Ruqiaya Hasan. 19884. Cohesion in English. London : Logman

Leech, Geoffrey N. 1983. Principles of Pragmatics. New York Logman 1979. A Communicative Grammar of English. London : Logman

Lyons, John. 1977. Introduction to Theoretical Linguistics. London : Cambridge University Press 1977. Semantics 2. Cambridge : University Press 1978. Semantics 1. Cambridge : University Press

Nababan, PNJ. 1987. Ilmu Pragmatik (Teori dan Penerapannya). Jakarta : PPLPTK 
Nancy, J. 1983. Assesing Children ${ }^{\wedge}$ s Language in Naturalistic Contexts. New Jersy : Prentice-Hall

Purwo, Bambang Kaswanti. 1984. Deiksis dalam Bahasa Indonesia. Jakarta : PN Balai Pustaka . 1990. Pragmatik Bahasa Indonesia Menyibak Kurikulum 1984. Yogyakarta : Kanisius

Samsuri. 1987. Analisis Bahasa. Jakarta : Erlangga

Sari, Nirmala. 1988. An Introduction to Linguistics. Jakarta Depdikbud 